\title{
Course Outcome and Programme Outcome in OBE: An Illustration in Engineering and Technology
}

\author{
Mr. Balaji $\mathbf{N}^{1}$, Dr. Karthik Pai B $\mathbf{H}^{2}$ \\ ${ }^{1,2}$ Department of Information Science \& Engineering \\ NMAM Institute of Technology, Nitte, Karkala, \\ Udupi - District, Karnataka, India \\ ${ }^{1}$ balaji.hiriyur@gmail.com \\ ${ }^{2}$ karthikpai@nitte.edu.in
}

\begin{abstract}
In NBA process of accreditation, OBE should fulfil the one of most important criteria such as attainment of Course Outcomes (COs') and Program Outcomes (POs'). In general we have direct and indirect assessment tools for the purpose of $\mathrm{CO}$ and $\mathrm{PO}$ attainment. The direct assessment tools can be Continuous Internal Evaluation - 1 (CIE - 1), Continuous Internal Evaluation - $2(\mathrm{CIE}-2)$ and End Semester Examination. Indirect tools can be Assignment or Quiz, Seminar or Group Seminar or Tutorial or Mini Project or Project Based Learning or Peer-to-Peer Learning. We have considered File Structures as a sample course and a set of COs have been defined along with the PO attainment planned. We have a detailed assessment scheme and plan of execution where students are participating in different assessments methods which includes both direct and indirect assessments. We have calculated CIE, Assignment and Seminar, SEE performance analysis. The Overall CO Attainment Level is calculated by using the formula $(\mathrm{E}=\mathrm{C} \times 0.7+\mathrm{D} \times 0.3)$ where $\mathrm{C}$ is Internal and $\mathrm{D}$ is external attainment level. Finally, we are considering the feedback from the students through Course Exit survey, where we are understanding the course outcomes module-wise in the student perspective and final PO attainment is calculated for each Course Outcome.
\end{abstract}

Keywords: Outcome Based Education, Continuous Internal Evaluation, Performance Analysis, Course Outcome, Programme Outcome, CO Attainment, Course Exit Survey, PO Attainment.

\section{Introduction}

To incorporate quality in technical Institutions, Government of India mandated the process of accreditation. In this view, National Board of Accreditation (NBA) plays a vital role for the process of accreditation. India has become permanent member of Washington Accord since 13 June, 2014 and this board instructed, technical institutions need to follow Outcome Based Education (OBE). In this process of accreditation, OBE should fulfil the one of most important criteria such as attainment of Course Outcomes (COs') and Program Outcomes (POs'). The POs designed and formulated for each programme by the Institute must be precise such as Engineering Knowledge, Problem Analysis, Design or Development of Solutions, Conduct Investigation on Complex Problems, Modern Tool Usage, The Engineer and Society, Environment and Sustainability, Ethics, Individual and Team Work, Communication, Project Management and Life-long Learning. The design and formulation of COs is done through the instructor and choice of the course or subject of consideration. These POs can be attained through the COs.

\section{Assessment Techniques}

As we know already, in general we have direct and indirect assessment tools for the purpose of $\mathrm{CO}$ and PO attainment. The direct assessment tools can be Continuous Internal Evaluation - 1 (CIE - 1), Continuous Internal Evaluation - 2 (CIE - 2) and End Semester Examination. Indirect tools can be Assignment or Quiz, Seminar or Group Seminar or Tutorial or Mini Project or Project Based Learning or Peer-to-Peer Learning. 
Table - 1 summarizes the tools to be used for assessment and attainment of COs and POs. As per the university (Visvesvaraya Technological University VTU) curriculum, we designed this kind of direct, indirect assessment tools to evaluate the overall attainment of the course which includes both $\mathrm{CO}$ and PO. Based on the modules, instructor designed the CO and their allotted PO mapping (High / Medium / Low).

\begin{tabular}{|c|c|c|c|}
\hline Direct Tools & $\begin{array}{c}\text { Weightage } \\
\text { Provided }\end{array}$ & Indirect Tools & $\begin{array}{c}\text { Weightage } \\
\text { Provided }\end{array}$ \\
\hline $\begin{array}{c}\text { Continuous Internal } \\
\text { Evaluation (CIE's) }\end{array}$ & $20 \%-30 \%$ & Assignment & $5 \%-10 \%$ \\
\hline End Semester Examination & $50 \%-60 \%$ & Quiz & $5 \%-10 \%$ \\
\hline & & Seminar / Group Seminar & $5 \%-10 \%$ \\
\hline & & Tutorial & $5 \%-10 \%$ \\
\hline & & Minor Project / Project Based Learning & $5 \%-10 \%$ \\
\hline & & Peer-To-Peer Learning & $5 \%-10 \%$ \\
\hline & & Course Exit Survey & $5 \%-10 \%$ \\
\hline
\end{tabular}

Table - 1: Direct and Indirect Tools Used

\section{Sample Course - File Structures}

We have considered the sample course namely, File Structures (FS), which is being offered in the sixth semester CS streams. We have considered the class of 61 students and designed a set of COs have been defined along with the PO attainment planned and it blooms taxonomy level.

\section{A. Designing Course Outcomes}

\begin{tabular}{|c|l|c|c|}
\hline CO No. & \multicolumn{1}{|c|}{ Description } & $\begin{array}{c}\text { Bloom's } \\
\text { Level }\end{array}$ & $\begin{array}{c}\text { Attainment } \\
\text { Planned }\end{array}$ \\
\hline C319.1 & $\begin{array}{l}\text { Choose appropriate file structure for storage representation and their mechanism to store } \\
\text { different types of files. }\end{array}$ & CL2 & $\mathbf{6 0 \%}$ \\
\hline C319.2 & $\begin{array}{l}\text { Organizing files using object oriented concepts and retrieve the same using advanced } \\
\text { concepts like inverted lists, selective indexes. }\end{array}$ & CL2 & $\mathbf{6 0 \%}$ \\
\hline C319.3 & $\begin{array}{l}\text { Identify a suitable sorting techniques to arrange the data and use of multi-level indexing } \\
\text { and B-tree techniques for organization of data in a file. }\end{array}$ & CL3 & $\mathbf{6 0 \%}$ \\
\hline C319.4 & Select suitable indexing and hashing technique for better performance to a given problem. & CL3 & $\mathbf{6 0 \%}$ \\
\hline $\mathbf{C 3 1 9 . 5}$ & $\begin{array}{l}\text { Choose some advanced file storage structures like Extendible hashing for better } \\
\text { performance. }\end{array}$ & CL4 & $\mathbf{6 0 \%}$ \\
\hline
\end{tabular}

Table -2 : List of Course Outcomes

Table 2 provides the course outcome for the sample course considered in this article and we have shown the Bloom's level with their target attainment. We have drafted the course outcomes based on the curriculum given in the university [1]. We had five modules in the sample course considered and for the every module we drafted a specific course outcome. 


\section{B. Course Outcome Mapping with Programme Outcomes}

\begin{tabular}{|c|c|c|c|c|c|c|c|c|c|c|c|c|}
\hline \multirow{2}{*}{ CO No. } & \multicolumn{10}{c|}{ Porgramme Outcomes (POs) } \\
\cline { 2 - 14 } & $\mathbf{1}$ & $\mathbf{2}$ & $\mathbf{3}$ & $\mathbf{4}$ & $\mathbf{5}$ & $\mathbf{6}$ & $\mathbf{7}$ & $\mathbf{8}$ & $\mathbf{9}$ & $\mathbf{1 0}$ & $\mathbf{1 1}$ & $\mathbf{1 2}$ \\
\hline C319.1 & 3 & 2 & 3 & 2 & 2 & 1 & 1 & 2 & 1 & - & 2 & 2 \\
\hline $\mathbf{C 3 1 9 . 2}$ & 3 & 2 & 3 & 2 & 2 & 1 & 2 & 2 & 2 & - & 3 & 2 \\
\hline C319.3 & 3 & 3 & 3 & 3 & 2 & 2 & 3 & 2 & 3 & - & 3 & 3 \\
\hline C319.4 & 3 & 3 & 3 & 3 & 2 & 2 & 3 & 2 & 3 & 1 & 3 & 3 \\
\hline C319.5 & 3 & 3 & 3 & 3 & 2 & 2 & 3 & 2 & 3 & 1 & 3 & 3 \\
\hline
\end{tabular}

We had a programme outcomes which was drafted from the NBA board [2], and the same POs are mapped in every course outcomes by providing the values such as 3 - High, 2 - Medium and 1 - Low.
These values are assigned based on the marks of the each COs for each student. The values are assigned based on the each module or unit importance, significance of the different concepts available.

\section{Evaluation Scheme}

\section{Continuous Internal Evaluation Scheme:}

\begin{tabular}{|c|c|c|}
\hline Name of the Assessment & Method of Assessment & $\begin{array}{c}\text { Maximum Marks } \\
\text { Allotted }\end{array}$ \\
\hline CIE -1 & Direct (Test) & 30 \\
\hline CIE -2 & Direct (Test) & 30 \\
\hline CIE - 3 & Direct (Test) & 30 \\
\hline \multicolumn{2}{|r|}{ (Average of CIE - 1, 2,3) Total } & $\mathbf{3 0}$ \\
\hline Assignment $-1 /$ Quiz -1 & Indirect & 05 \\
\hline $\begin{array}{c}\text { Peer-to-Peer Learning / } \\
\text { Seminar }\end{array}$ & Indirect & 05 \\
\hline \multicolumn{2}{|r}{ Total } & $\mathbf{4 0}$ \\
\hline
\end{tabular}

End Semester Examination Scheme:

\begin{tabular}{|c|c|c|c|}
\hline Name of the Assessment & $\begin{array}{c}\text { Method of } \\
\text { Assessment }\end{array}$ & $\begin{array}{c}\text { Maximum Marks } \\
\text { Allotted }\end{array}$ & Weightage in Marks \\
\hline End Semester Examination & Direct (Examination) & 100 & 60 \\
\hline \multicolumn{3}{|r|}{ Total } & $\mathbf{6 0}$ \\
\hline
\end{tabular}

Table -4 : Consolidated Evaluation (CIE + End Semester Exam $=40+60=100$ Marks $)$

Table 4 provides the detailed assessment scheme and plan of execution where students are participating in different assessments methods which includes both direct and indirect assessments. This plan of assessment gives the split of overall marks into different parts of the evaluation such as CIE,
Assignment, Quiz, Seminar etc., and finally the end semester examination. Finally, we are considering the feedback from the students, where we are understanding the course outcomes module-wise in the student perspective. 


\section{CIE Performance Analysis}

In the $\mathrm{CIE}-1$, there will be four questions, two from first two modules. Students need to answer one question from each module. Each questions holds 15 marks and CIE - 1 covers first two course outcomes.
Table -5 provides the performance analysis of CIE 1. This analysis demonstrates that the average attainment of course outcome $\mathrm{C} 319.1$ has $79.18 \%$ and C319.2 has $72.81 \%$.

\begin{tabular}{|c|c|c|c|c|}
\hline Question No. & CO Mapped & Students Attempted & Average Marks & Percentage of Score \\
\hline 1 & 1 & 34 & 13 & $87 \%$ \\
\hline 2 & 1 & 24 & 10.5 & $70 \%$ \\
\hline 3 & 2 & 22 & 11 & $73 \%$ \\
\hline 4 & 2 & 34 & 12.5 & $83 \%$ \\
\hline
\end{tabular}

Table - 5: CIE - 1 Performance Analysis

Similarly table -6 provides the performance analysis of CIE - 2 and this constitutes second (some parts the $\mathrm{CO}$ are unattained) and third course outcome. This analysis demonstrates that the average attainment of course outcome C319.2 has $67.82 \%$ and C319.3 has $64.40 \%$.

\begin{tabular}{|c|c|c|c|c|}
\hline Question No. & CO Mapped & Students Attempted & Average Marks & Percentage of Score \\
\hline 1 & 2 & 37 & 14 & $93 \%$ \\
\hline 2 & 2 & 17 & 12.5 & $83 \%$ \\
\hline 3 & 3 & 31 & 12 & $80 \%$ \\
\hline 4 & 3 & 27 & 11.5 & $77 \%$ \\
\hline \multicolumn{4}{|r|}{ Table - 6: CIE - 2 Performance Analysis } \\
\hline
\end{tabular}

Similarly, table -7 provides the performance analysis of CIE - 3 and this constitutes fourth and fifth course outcome. This analysis demonstrates that the average attainment of course outcome C319.4 has $64.64 \%$ and C319.5 has $68 \%$.

\begin{tabular}{|c|c|c|c|c|}
\hline Question No. & CO Mapped & Students Attempted & Average Marks & Percentage of Score \\
\hline 1 & 4 & 31 & 13 & $87 \%$ \\
\hline 2 & 4 & 15 & 11.5 & $77 \%$ \\
\hline 3 & 5 & 40 & 14.5 & $97 \%$ \\
\hline 4 & 5 & 05 & 11.5 & $77 \%$ \\
\hline
\end{tabular}

\section{E. Assignment and Seminar Performance Analysis}

We have given assignment questions from module -1 $\& 2$ and seminar (peer-to-peer learning) concepts from module $-3,4 \& 5$. We are planned to cover attain in all the course outcomes, since the end semester examination doesn't contain any $\mathrm{CO}$ and $\mathrm{PO}$ mapping. Because this curriculum is designed by the university for the partial fulfilment of undergraduate Bachelor of

\begin{tabular}{|c|c|c|c|c|c|}
\hline $\begin{array}{c}\text { Name of the } \\
\text { Assignment }\end{array}$ & CO Mapped & $\begin{array}{c}\text { Students } \\
\text { Attempted }\end{array}$ & $\begin{array}{c}\text { Average } \\
\text { Marks }\end{array}$ & $\begin{array}{c}\text { Percentage of } \\
\text { Score }\end{array}$ & COs Attainment \\
\hline Assignment -1 & 1 & 61 & 4.5 & $90 \%$ & $34.90 \%$ \\
\hline Assignment -1 & 2 & 61 & 4.5 & $90 \%$ & $26.44 \%$ \\
\hline Seminar & 3 & 61 & 4 & $80 \%$ & $31.94 \%$ \\
\hline Seminar & 4 & 61 & 4.5 & $90 \%$ & $27.24 \%$ \\
\hline Seminar & 5 & 61 & 4.25 & $85 \%$ & $34.56 \%$ \\
\hline
\end{tabular}

Table - 8: Assignment and Seminar Performance Analysis

\section{F. End Semester Examination Performance Analysis}

Engineering course in Information Science and Engineering (ISE). This is the behind that, the attainment calculation for all the $\mathrm{CO}$ and $\mathrm{PO}$ which is considered in assignment and seminar. 
End semester examination question paper has been designed by the university expert professors, which doesn't contain any CO mapping and PO mapping as well. Since this shows that, there is no attainment level at the end of semester examinations. But, we have calculated the pass percentage level based on their marks in the examination and the same has been considered for the final attainment. Pass percentage includes first class, second class, pass and fail. For the above considered course File Structures we got the overall percentage as $47.72 \%$ after the end semester examinations.

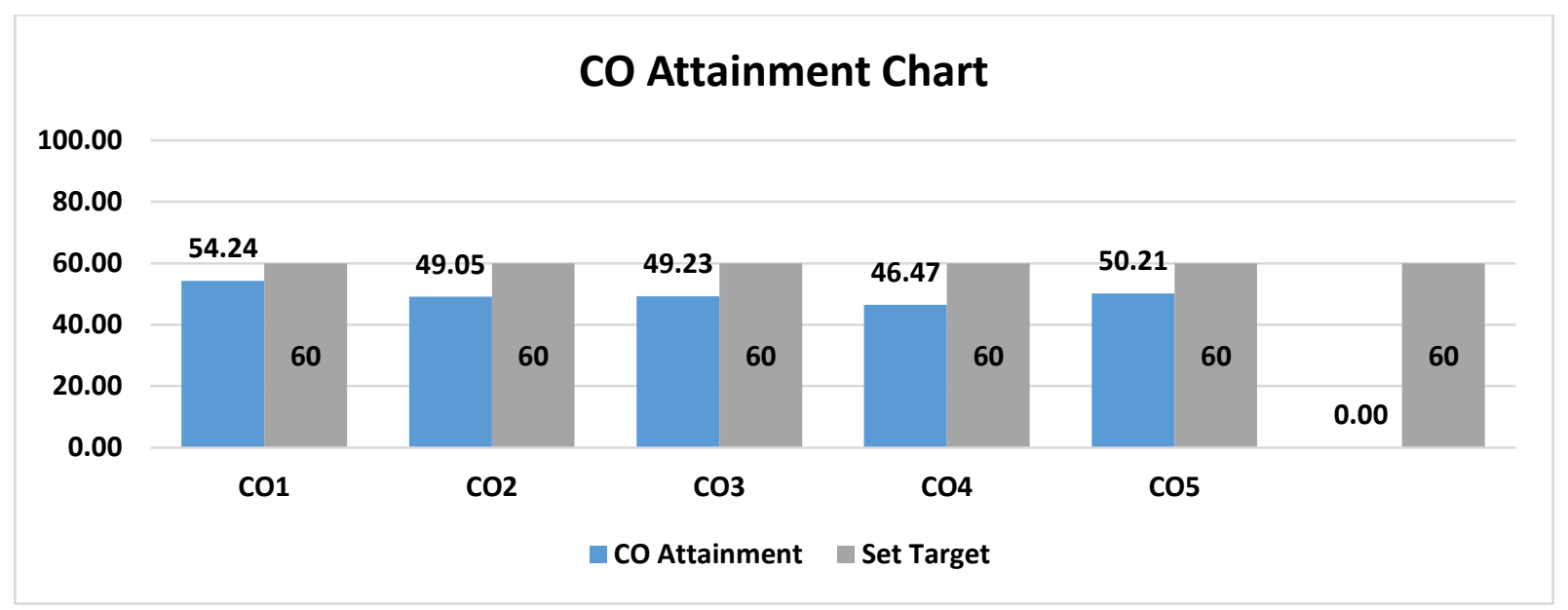

Fig 1: Course Outcome Attainment Chart

Figure 1 and table -9 provides the course outcome attainment which includes direct and indirect attainment of the course.

\begin{tabular}{|c|c|c|c|c|c|c|}
\hline COs & $\begin{array}{c}\text { *Assigned } \\
\text { Target } \\
\text { Level }\end{array}$ & $\begin{array}{c}\text { Direct Tool } \\
\text { Attainment } \\
\text { Level (A) }\end{array}$ & $\begin{array}{c}* * \text { Indirect } \\
\text { Tool } \\
\text { Attainment } \\
\text { Level }(B)\end{array}$ & $\begin{array}{c}\text { Internal } \\
\text { Overall } \\
\text { Attainment } \\
\text { Level }(\mathbf{C}= \\
(\mathbf{A}+\mathrm{B}) / 2) \\
\end{array}$ & $\begin{array}{c}* * * \text { External } \\
\text { Examination } \\
\text { Attainment } \\
\text { Level (D) }\end{array}$ & $\begin{array}{c}\text { Overall Attainment } \\
\text { Level } \\
(\mathrm{E}=\mathrm{C} \times \mathbf{0 . 7}+\mathrm{D} \times \mathbf{0 . 3})\end{array}$ \\
\hline C319.1 & \multirow[t]{5}{*}{$60.00 \%$} & 79.18 & 34.90 & 57.04 & \multirow[t]{5}{*}{$47.72 \%$} & 54.24 \\
\hline C319.2 & & 72.81 & 26.44 & 49.63 & & 49.05 \\
\hline C319.3 & & 67.82 & 31.94 & 49.88 & & 49.23 \\
\hline C319.4 & & 64.64 & 27.24 & 45.94 & & 46.47 \\
\hline C319.5 & & 68.00 & 34.56 & 51.28 & & 50.21 \\
\hline
\end{tabular}

\section{G. Course Exit Survey}

The course exit survey has been taken from the students, where the survey contains all the course outcomes and the students will rate their understanding level of attainment as Excellent-5, Good-4, Average-3, Below Average-2 and Poor-1.

\begin{tabular}{|l|c|c|c|c|c|}
\hline \multicolumn{1}{|c|}{ Course Exit Survey Analysis } \\
\hline & C319.1 & C319.2 & C319.3 & C319.4 & C319.5 \\
\hline
\end{tabular}




\begin{tabular}{|c|c|c|c|c|c|}
\hline Option 1 & 1 & 2 & 1 & 1 \\
\hline Option 2 & 2 & 1 & 2 & 1 & 2 \\
\hline Option 3 & 12 & 14 & 10 & 9 & 10 \\
\hline Option 4 & 15 & 15 & 18 & 19 & 11 \\
\hline Option 5 & 35 & 35 & 38 & 35 & 36 \\
\hline Total no. of students & 65 & 67 & 69 & 65 & 60 \\
\hline No. of students opted 3 and high & 62 & 64 & 66 & 63 & 57 \\
\hline \% of students opted 3 and high & $95.38 \%$ & $95.52 \%$ & $95.65 \%$ & $96.92 \%$ & $95.00 \%$ \\
\hline Attainment Level & 5 & 5 & 5 & 5 & 5 \\
\hline
\end{tabular}

Table - 10: Course Exit Survey

Table -10 provides the detailed course exit survey of the above mentioned course. This can be computed based on the understanding of the every COs in the perception of students. Every student is rating the every $\mathrm{CO}$ through the values ranging from 1 to 5 , where 5 is the highest score for the $\mathrm{CO}$ and 1 is the least score for the $\mathrm{CO}$. Likewise, we are taking the survey for all COs, and calculating the survey based on their understanding and its value assignments.

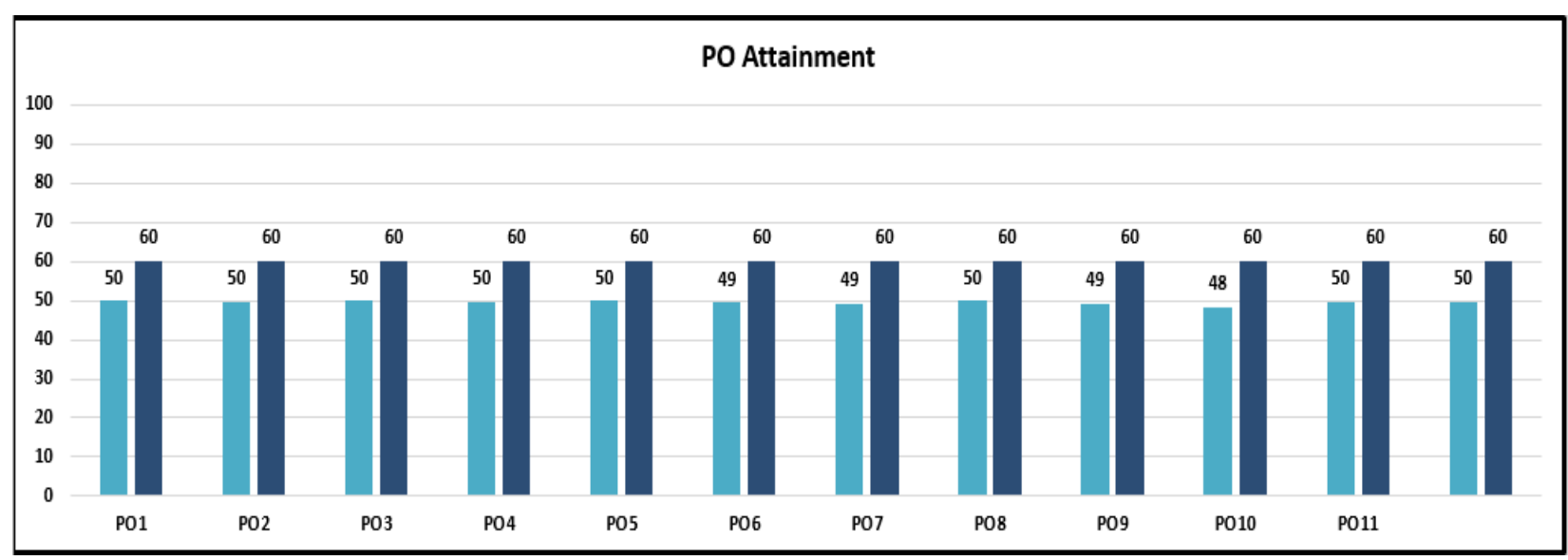

Fig 2: Programme Outcome Attainment Chart

Figure -2 and table -11 provides the programme outcome for the proposed course outcome in the sample course File Structures.

\begin{tabular}{|c|c|c|c|c|c|c|c|c|c|c|c|c|}
\hline \multirow{2}{*}{ CO No. } & \multicolumn{10}{|c|}{ Porgramme Outcomes (POs) } \\
\cline { 2 - 14 } & $\mathbf{1}$ & $\mathbf{2}$ & $\mathbf{3}$ & $\mathbf{4}$ & $\mathbf{5}$ & $\mathbf{6}$ & $\mathbf{7}$ & $\mathbf{8}$ & $\mathbf{9}$ & $\mathbf{1 0}$ & $\mathbf{1 1}$ & $\mathbf{1 2}$ \\
\hline $\mathbf{C 3 1 9 . 1}$ & 1.63 & 1.08 & 1.63 & 1.08 & 1.08 & 0.54 & 0.54 & 1.08 & 0.54 & - & 1.08 & 1.08 \\
\hline $\mathbf{C 3 1 9 . 2}$ & 1.47 & 0.98 & 1.47 & 0.98 & 0.98 & 0.49 & 0.98 & 0.98 & 0.98 & - & 1.47 & 0.98 \\
\hline
\end{tabular}




\begin{tabular}{|c|c|c|c|c|c|c|c|c|c|c|c|c|}
\hline C319.3 & 1.48 & 1.48 & 1.48 & 1.48 & 0.98 & 0.98 & 1.48 & 0.98 & 1.48 & - & 1.48 & 1.48 \\
\hline C319.4 & 1.39 & 1.39 & 1.39 & 1.39 & 0.93 & 0.93 & 1.39 & 0.93 & 1.39 & 0.46 & 1.39 & 1.39 \\
\hline C319.5 & 1.51 & 1.51 & 1.51 & 1.51 & 1.00 & 1.00 & 1.51 & 1.00 & 1.51 & 0.50 & 1.51 & 1.51 \\
\hline
\end{tabular}

Table - 11: Final PO Attainment

Table -12 provides the overall result analysis for the sample course File Structure which includes the CIE final marks and end semester examination marks as well, which the overall result for the sample course.

\begin{tabular}{|c|c|c|c|c|c|c|}
\hline \multicolumn{7}{|c|}{ Analysis } \\
\hline Range & CIE-1 (30) & CIE-2 (30) & CIE-3 (30) & CIE (40) & $\begin{array}{c}\text { External (60) } \\
\text { Number of } \\
\text { Students }\end{array}$ & $\begin{array}{l}\text { Total } \\
\text { (100) }\end{array}$ \\
\hline$<60 \%$ & 12 & 15 & 16 & 8 & 36 & 22 \\
\hline$>=60 \%$ and $<=70 \%$ & 11 & 19 & 13 & 7 & 17 & 23 \\
\hline$>70 \%$ & 33 & 22 & 26 & 40 & 2 & 10 \\
\hline Maximum & 30 & 29 & 30 & 39 & 48 & 84 \\
\hline Minimum & 9 & 0 & 5 & 18 & 3 & 24 \\
\hline Mean & 21.98 & 19.71 & 20.24 & 30.11 & 31.24 & 61.51 \\
\hline
\end{tabular}

\section{Conclusion and Future Scope}

In this article, we have considered a real time data for analyzing the attainment of Course Outcomes and Programme Outcomes. These are evident that the actual attainment of the Course Outcomes and Programme Outcomes are meeting the planned expectations. The direct and indirect tools used for the assessment and their weightages can be suitably selected as per the requirement of the Institute. In further, we are planning to have a provision to design the end semester examination which includes the course outcome mapping and programme outcome mapping. This will automatically boost-up the attainment level in direct and indirect assessments tools and by default it can increase the attainment level at the end of semester examinations. Based on the course exit survey taken from the students, we are planning to incorporate the feedback given and we will focus on the less attainment course outcome and taking necessary action plan for the next academic year in the same sample course.

In initial academic year, we have chosen the attainment level as $60 \%$, since the sample course has been designed drafted with COs and POs attainment values. Once we reached the above mentioned attainment level, we are planning to attain more in the subsequent academic year such as $70 \%$ and so on. This will automatically boost-up the students understanding level in the sample course, and he or she will nurture the depth knowledge of the course, which helps in placement activities and higher studies.

\section{References}

[1] www.vtu.ac.in/pdf/cbcs/38sem2019/isesyll.pdf (Visvesvaraya Technological University Website).

[2] www.nbaind.org

(National Board of Accreditation Website).

[3] https://em.wikipedia.org/wiki/Outcome-basededucation 